\title{
Article \\ Extracellular Vesicles Derived-LAT1 mRNA as a Powerful Inducer of Colorectal Cancer Aggressive Phenotype
}

\author{
Cristina Almeida ${ }^{1,2,+}$, Ana Luísa Teixeira ${ }^{1,3, *,+} \mathbb{D}$, Francisca Dias ${ }^{1,+} \mathbb{D}$, Vera Machado ${ }^{1}$, Mariana Morais ${ }^{1} \mathbb{D}$, \\ Gabriela Martins ${ }^{4}$, Carlos Palmeira ${ }^{4,5,6}$, Maria Emília Sousa ${ }^{4}$, Inês Godinho ${ }^{4}$, Sílvia Batista ${ }^{7}$, \\ Bruno Costa-Silva ${ }^{7}$ (D) and Rui Medeiros $1,2,3,6,8$ (D)
}

check for updates

Citation: Almeida, C.; Teixeira, A.L.; Dias, F.; Machado, V.; Morais, M.; Martins, G.; Palmeira, C.; Sousa, M.E.; Godinho, I.; Batista, S.; et al. Extracellular Vesicles Derived-LAT1 mRNA as a Powerful Inducer of Colorectal Cancer Aggressive Phenotype. Biology 2022, 11, 145. https://doi.org/10.3390/ biology11010145

Academic Editor: Pilar Roca

Received: 9 December 2021

Accepted: 7 January 2022

Published: 15 January 2022

Publisher's Note: MDPI stays neutral with regard to jurisdictional claims in published maps and institutional affiliations.

Copyright: (C) 2022 by the authors. Licensee MDPI, Basel, Switzerland. This article is an open access article distributed under the terms and conditions of the Creative Commons Attribution (CC BY) license (https:// creativecommons.org/licenses/by/ $4.0 /)$.
1 Molecular Oncology and Viral Pathology Group, Research Center of IPO Porto (CI-IPOP)/ RISE@CI-IPOP (Health Research Network), Portuguese Oncology Institute of Porto (IPO Porto)/Porto Comprehensive Cancer Center (Porto.CCC), Rua Dr. António Bernardino de Almeida, 4200-072 Porto, Portugal; cristina.almeida@ipoporto.min-saude.pt (C.A.); francisca.carvalho.dias@ipoporto.min-saude.pt (F.D.); vera.pereira.machado@ipoporto.min-saude.pt (V.M.); mariana.gomes.morais@ipoporto.min-saude.pt (M.M.); ruimedei@ipoporto.min-saude.pt (R.M.)

2 Research Department of the Portuguese League against Cancer Regional Nucleus of the North (LPCC-NRN), Estrada da Circunvalação 6657, 4200-177 Porto, Portugal

3 ICBAS School of Medicine and Biomedical Sciences, University of Porto (UP), Rua Jorge Viterbo Ferreira 228, 4050-513 Porto, Portugal

4 Immunology Department, Portuguese Oncology Institute of Porto (IPO Porto), Rua Dr. António Bernardino de Almeida, 4200-072 Porto, Portugal; gmartins@ipoporto.min-saude.pt (G.M.); carlospalmeira@ipoporto.min-saude.pt (C.P.); emilia.sousa@ipoporto.min-saude.pt (M.E.S.); ines.godinho@ipoporto.min-saude.pt (I.G.)

5 Pathology and Experimental Therapeutic Group, Research Center of IPO Porto (CI-IPOP)/RISE@CI-IPOP (Health Research Network), Portuguese Oncology Institute of Porto (IPO Porto)/Porto Comprehensive Cancer Center (Porto.CCC), Rua Dr. António Bernardino de Almeida, 4200-072 Porto, Portugal

6 Fernando Pessoa Research, Innovation and Development Institute (I3ID FFP), Fernando Pessoa University (UFP), Praça 9 de Abril 349, 4249-004 Porto, Portugal

7 Systems Oncology Group, Champalimaud Research, Champalimaud Centre for the Unknown, Av. Brasília, 1400-038 Lisbon, Portugal; silvia.batista@research.fchampalimaud.org (S.B.); bruno.costadasilva@research.fchampalimaud.org (B.C.-S.)

8 Faculty of Medicine, University of Porto (FMUP), Alameda Prof. Hernâni Monteiro, 4200-319 Porto, Portugal

* Correspondence: ana.luisa.teixeira@ipoporto.min-saude.pt; Tel.: +351-225-084-000 (ext. 5410)

+ These authors contributed equally to this work.

Simple Summary: The metastatic spread of tumor cells to the liver is one of the most common causes of mortality in CRC. Extracellular vesicles are currently considered vehicles of metastization, playing a role in the modification of the recipient cell's phenotype. LAT1 and ASCT2 are amino acids transporters associated with increased proliferation in CRC. This study analyzed the effect of LAT1 and ASCT2 mRNAs derived from CRC-EVs in the phenotype modulation of recipient cells. In this study we demonstrate LAT1-EVs mRNA involvement in recipient cells' phenotype modulation, conferring advantages in cell migration and proliferation.

Abstract: Colorectal cancer (CRC) is the third most common cancer in the world and represents the third most deadly tumor worldwide. About $15-25 \%$ of patients present metastasis in the moment of diagnosis, the liver being the most common site of metastization. Therefore, the development of new therapeutic agents is needed, to improve the patients' prognosis. Amino acids transporters, LAT1 and ASCT2, are described as upregulated in CRC, being associated with a poor prognosis. Extracellular vesicles have emerged as key players in cell-to-cell communication due to their ability to transfer biomolecules between cells, with a phenotypic impact on the recipient cells. Thus, this study analyzes the presence of LAT1 and ASCT2 mRNAs in CRC-EVs and evaluates their role in phenotype modulation in a panel of four recipient cell lines (HCA-7, HEPG-2, SK-HEP-1, HKC-8) We found that HCT 116-EVs carry LAT1, ASCT2 and other oncogenic mRNAs being taken up by recipient cells. Moreover, the HCT 116-EVs' internalization was associated with the increase of LAT1 mRNA in SK-HEP-1 cells. We also observed that HCT 116-EVs induce a higher cell migration capacity 
and proliferation of SK-HEP-1 and HKC-8 cells. The present study supports the LAT1-EVs' mRNA involvement in cell phenotype modulation, conferring advantages in cell migration and proliferation.

Keywords: colorectal cancer (CRC); mRNAs; LAT1; ASCT2; extracellular vesicles (EV's)

\section{Introduction}

Colorectal cancer (CRC) represents $10 \%$ of all diagnosed cancers, being the third most frequent cancer worldwide [1]. According to World Health Organization (WHO), CRC is also the third most deadly cancer [2]. In fact, patients that are diagnosed at advanced stages of CRC present 5-year survival rates of $12 \%$, compared to the $90 \%$ observed in patients diagnosed at early stages of the disease [3]. However, approximately $15-25 \%$ of CRC patients present a metastatic disease at diagnosis, with an increase to $50 \%$ during the course of the disease. The liver is the most frequent initial site of metastases establishment, and although extremally rare, kidney metastasis formation can also occur [4-7]. Therefore, the definitions of new prognosis, follow-up molecular biomarkers and therapeutic agents are imperative to improve CRC patients' care and promote a more individualized and precise follow-up.

In 2011, metabolic reprogramming was defined as a cancer "hallmark", being essential to support tumor cells' growth and progression in response to altered microenvironments [8]. In fact, cancer cells present plasticity and adaptative capacity in response to microenvironment alterations to continue to proliferate and adapt to dynamic changes, the amino acid (AA) bioavailability being an important necessity to answer the high demand of nutrients during the cancer progression [9]. Thus, solute carriers' transporters (SLCs) present a key role in CRC progression, since these transmembrane carriers are involved in the transport of several solutes such as AA, lipids and inorganic solutes, participating in key carcinogenesis processes, such as proliferation, apoptosis, invasion and metastases formation $[10,11]$.

Recently, the overexpression of some AA transporters was associated with the increased AA demand of cancer cells [12]. LAT1 and ASCT2 are two of the SLCs deregulated during CRC progression $[10,13,14]$. LAT1 is a sodium $\left(\mathrm{Na}^{+}\right)$and $\mathrm{pH}$ independent transporter, involved in the essential amino acids' (EAAs) transport [14-16]. It forms a heterodimer complex with CD98 to import large and neutral AAs, in exchange for the efflux of intracellular substrates, including EAAs and glutamine [12,15-17]. On the other hand, ASCT2 is a Na${ }^{+}$and $\mathrm{pH}$ dependent transporter, responsible for the transport of glutamine inside of cells [18-21]. The overexpression of LAT1 and ASCT2 is related with patients' poor prognosis $[18,22-24]$. Furthermore, the upregulation of LAT1 is frequently observed in CRC, liver and kidney cancers [15,16,22,24-26], and its knockdown has been associated with the reduction of leucine uptake and cell proliferation [16]. ASCT2 overexpression has also been reported in several cancers, including breast, lung cancer and hepatocellular carcinoma, and its expression levels were also associated with tumor depth and the vascular invasion in KRAS-mutant CRC [27-31]. Interestingly, Toda and co-workers observed that ASCT2-knockdown presents a more suppressive effect on cell growth than glutamine depletion [27]. Namikawa and co-workers showed that the overexpression of both transporters in hepatocellular carcinoma was associated with metastases development and disease aggressiveness [32].

Extracellular vesicles (EV's) have been recognized as key mediators of cell communication and microenvironment modulation. They can transfer molecular information (such as DNA, RNA and protein) between cells and modify their phenotype [33]. EVs are small nanovesicles surrounded by a membrane composed by a lipid bilayer and hydrophilic proteins, being released by numerous cell types, both in physiologic and pathologic conditions [34-38]. EVs play an important role in the pre-metastatic niche establishment, promoting the upregulation of inflammatory molecules, immune suppression, increasing 
angiogenesis and vascular permeability, and determining organotropism metastases [39]. In fact, Chiba and co-workers have reported that the EVs secreted from human CRC cells can transfer RNAs to liver cells, and modify their phenotype features, inducing invasion, intravasation and metastatic capacity [40]. Thus, considering the EVs' ability to modify the phenotype of recipient cells, our aim was to analyze the effect of LAT1 and ASCT2 mRNA derived CRC-cells' EVs on the phenotype modulation of recipient cells to clarify their potential tropism.

\section{Materials and Methods}

\subsection{Cell Culture}

A panel of five cell lines was used: HCT 116 and HCA-7 (CRC cell lines), SK-HEP-1 and HEPG-2 (hepatocellular carcinoma cell lines) and HKC-8 (human-derived normal renal proximal epithelial tubular cell line). HCT 116 and SK-HEP-1 cells were kindly provided by the Biomedicine Department of Faculty of Medicine of Porto University and HKC-8 was obtained from the Department of Genetics of University Medical Center of Groningen. HEPG-2 cell line was provided by the Basic and Clinical Research on Iron Biology Group from I3S. HCA-7 was obtained from American Type Culture Collection (ATCC ${ }^{\circledR}$ RRID: CVCL_0289). Briefly, HCT 116 cells were maintained in McCoy's 5a medium (Sigma-Aldrich ${ }^{\circledR}$, St. Louis, MO, USA), supplemented with $2.2 \mathrm{~g} / \mathrm{L}$ sodium bicarbonate (Merck ${ }^{\circledR}$, Darmstadt, Germany), 6 g/ L Hepes (Sigma-Aldrich ${ }^{\circledR}$ ), 10\% fetal bovine serum (FBS) (Gibco-Thermo Fisher Scientific ${ }^{\circledR}$, Waltham, MA, USA) and 1\% of pen-strep (penicillium-streptomycin mixture) $\left(\mathrm{Gibco}^{\circledR}{ }^{\circledR}\right.$, Thermo Fisher Scientific $\left.{ }^{\circledR}\right)$. The SK-HEP-1 cells were maintained in RPMI medium (Sigma-Aldrich ${ }^{\circledR}$ ), with 2.2. g/L sodium bicarbonate $\left(\right.$ Merck $\left.^{\circledR}\right), 6$ g/L Hepes (Sigma-Aldrich ${ }^{\circledR}$ ), 10\% FBS (Gibco ${ }^{\circledR}$, Thermo Fisher Scientific ${ }^{\circledR}$ ) and $1 \%$ of pen-strep $\left(\right.$ Gibco $^{\circledR}$, Thermo Fisher Scientific $\left.{ }^{\circledR}\right)$. The HCA-7 and HEPG-2 cells were maintained in DMEM medium (Gibco ${ }^{\circledR}$, Thermo Fisher Scientific ${ }^{\circledR}$ ), supplemented with $10 \%$ of FBS (Gibco ${ }^{\circledR}$, Thermo Fisher Scientific ${ }^{\circledR}$ ) and $1 \%$ of pen-strep (Gibco ${ }^{\circledR}$, Thermo Fisher Scientific $\left.{ }^{\circledR}\right)$. Additionally, HKC-8 cells were maintained in DMEM/F12 medium supplemented with ITS (Insulin-Transferrine-Selenum) (Sigma-Aldrich ${ }^{\circledR}$ ), EGF (Epidermal Growth Factor) (Sigma-Aldrich ${ }^{\circledR}$ ), Hepes buffer (Sigma-Aldrich ${ }^{\circledR}$ ), pen-strep $\left(\right.$ Gibco $^{\circledR}$, Thermo Fisher Scientific ${ }^{\circledR}$ ) and hydrocortisone (Sigma-Aldrich ${ }^{\circledR}$ ). The cell lines were kept in an incubator at $37^{\circ} \mathrm{C}$ with $5 \%$ of $\mathrm{CO}_{2}$. All cells were routinely tested for mycoplasma presence every two weeks, being free from contamination.

\subsection{EVs' Isolation}

The HCT 116 cell line was used as EVs' producer. Briefly, the HCT 116 cell line was cultured in the normal medium until it reached $80-90 \%$ of confluence. The medium was then replaced by McCoy's 5A supplemented with 10\% of exosome-depleted (exo-free) FBS (Thermo Fisher Scientific ${ }^{\circledR}$ ) (McCoy's Exo-free) for $48 \mathrm{~h}$. Then, the cell culture medium was harvested and centrifuged for $30 \mathrm{~min}$ at $3500 \mathrm{rpm}$ at $4{ }^{\circ} \mathrm{C}$. Subsequently, the supernatant was filtered with a $0.22 \mu \mathrm{m}$ filter (GE Healthcare Whatman ${ }^{\mathrm{TM}}$, Chicago, IL, USA). The purified supernatant and the EV's isolation reagent (Total Exosome Isolation Reagent) (Thermo Fisher Scientific ${ }^{\circledR}$ ) were mixed in a 2:1 proportion and incubated overnight at $4{ }^{\circ} \mathrm{C}$. The mixture was then centrifuged at $10,000 \times g$, at $4^{\circ} \mathrm{C}$, for $1 \mathrm{~h}$ and the pellet (EVs' fraction) was resuspended in filtered PBS (Gibco ${ }^{\circledR}$, Thermo Fisher Scientific ${ }^{\circledR}$ ).

\subsection{EVs' Characterization}

The HCT 116-EVs were analyzed for size distribution by the NS300 Nanoparticle Tracking Analysis (NTA) system (NanoSight-Malvern Panalytical, Malvern, UK). Samples were pre-diluted in filtered PBS $1 X\left(\right.$ Gibco $^{\circledR}$, Thermo Fisher Scientific $\left.{ }^{\circledR}\right)$ to achieve a concentration within the range for optimal NTA analysis. Video acquisitions were made using a camera level of 16 and a threshold between 5 and 7 . Five to nine videos of $30 \mathrm{~s}$ were captured per sample. Analysis of particle size distribution was performed with NTA software v3.4 (Figure 2A). EVs' quantification in our isolates was made using a CFSE (Carboxyfluorescein 
succinimidyl ester) (ab113853-Abcam ${ }^{\circledR}$, Cambridge, UK) staining protocol, optimized for a conventional flow cytometer, using a BD FACS Canto II flow cytometer (BD Biosciences, Franklin Lakes, NJ, USA). Before acquisition, an intensive distilled water cleaning of the fluidic system of the cytometer was performed. We defined the cytometer settings for EVs' analysis using Megamix-Plus SSC beads (BioCytex, Marseille, France), a mix of fluorescent beads of different diameters that cover a variety of microparticle size ranges $(0.16$ to $0.40 \mu \mathrm{m}$ ) (Figure 2B) and use side scatter (SSC) as a size-related parameter. The EVs' suspension was stained with CFSE at a final concentration of $2 \mu \mathrm{M}$ and incubated in the dark at $37^{\circ} \mathrm{C}$ for $45 \mathrm{~min}$. Finally, EVs' morphology and shape were analyzed by Transmission Electron Microscopy (TEM) (Figure 2E).

\subsection{Quantitative Real-Time Polymerase Chain Reaction ( $q R T-P C R$ )}

The mRNA from all the cell lines and HCT 116-EVs was isolated using the GRS Total RNA Kit- Blood \& Cultured Cells (Gibco ${ }^{\circledR}$, Thermo Fisher Scientific ${ }^{\circledR}$ ), according to the manufacturer's protocol. When the cells reached a confluence of $80-90 \%$, the culture medium was collected for EVs' isolation and, subsequently, $3 \times 10^{6}$ cells were used for mRNA extraction. For each condition used in this study, the procedure was replicated three times. The mRNA samples were used as templates for complementary cDNA synthesis, using the High-Capacity cDNA Reverse Transcription Kit (Applied Biosystems ${ }^{\circledR}$, Thermo Fisher Scientific ${ }^{\circledR}$, Waltham, MA, USA), according to the manufacturer's protocol. The mRNA expression levels were analyzed by Real Time PCR and the reactions were carried out on a StepOne ${ }^{\mathrm{TM}}{ }_{\mathrm{qPCR}}$ Real-Time PCR machine, containing 1X Taqman ${ }^{\mathrm{TM}}$ Fast advanced master mix (Applied Biosystems ${ }^{\circledR}$, Thermo Fisher Scientific ${ }^{\circledR}$ ), with 1X probes (TaqMan ${ }^{\circledR}$ mRNA Expression Assays: LAT1 (Hs01001186_m1), ASCT2 (Hs01056542_m1), HIF1-A (Hs00153153_m1), EGFR (Hs01076078_m1), VEGFA (Hs00900055_m1), CXCR4 (Hs00607978_s1) and cDNA sample ( $\approx 50 \mathrm{ng})$. B2M (Beta-2Macroglobulin (Hs99999907_m1)) was used as endogenous control for mRNA data normalization and data analysis was made using StepOneTM Sofware v2.2 (Applied Biosystems ${ }^{\circledR}$, Thermo Fisher Scientific $\left.{ }^{\circledR}\right)$. All quantification reactions were performed in duplicate and negative controls were included in each run.

\subsection{EVs' Uptake Studies}

The internalization of HCT 116-EVs by the recipient cells (HCA-7, SK-HEP-1, HEPG-2 and HKC-8) was analyzed through fluorescence analysis. Additionally, their impact in the recipient cells was analyzed in terms of cell proliferation, migration capacity, transcription, and protein levels.

Thus, $2 \times 10^{5}$ cells of recipient cells were seeded in a 6 multi-well plate and maintained, according to the conditions previously described. When the cells reached $60-70 \%$ of confluence, the medium was changed to exo-free medium and the HCT 116-EVs were administrated in two different concentrations: (1) $5.3 \times 10^{8} \mathrm{EVs} / \mathrm{mL}$ (HCT 116-EVs condition 1) and $15.9 \times 10^{8} \mathrm{EVs} / \mathrm{mL}$ (HCT 116-EVs condition 2).

\subsubsection{EVs' Uptake by Recipient Cells}

Firstly, the HCT 116-EVs were labeled with $0.5 \mu \mathrm{L}$ of CFSE membrane-permeable fluorescent dye $\left(\mathrm{ab} 113853-\mathrm{Abcam}^{\circledR}\right)$, for $45 \mathrm{~min}$, in the dark, at $37^{\circ} \mathrm{C}$. Then, the labeled HCT 116-EVs' conditions 1 and 2 were resuspended in fresh culture medium and added to the HCA-7, SK-HEP-1, HEPG-2 and HKC-8 cell lines which were cultured in cover slips in 6 multi-well plates, for $24 \mathrm{~h}$. Subsequently, each well was washed with PBS 1X (Gibco ${ }^{\circledR}$, Thermo Fisher Scientific ${ }^{\circledR}$ ), three times, and the cells were incubated with $4 \%$ paraformaldehyde for $15 \mathrm{~min}$, followed by three washes with PBS 1X (Gibco ${ }^{\circledR}$, Thermo Fisher Scientific $\left.{ }^{\circledR}\right)$. Then, $1 \mathrm{~mL}$ of DAPI $\left(4^{\prime}, 6^{\prime}\right.$-diamino-2-fenil-indol) (Thermo Fisher Scientific $\left.{ }^{\circledR}\right)$ was added to each well for $5 \mathrm{~min}$ to stain the cell's nucleus. Finally, Kaiser's glycerol gelatin (Merck ${ }^{\circledR}$ ) was added to the cover slip and then preparations were analyzed using an Olympus ${ }^{\circledR}$ IX51 microscope. 


\subsubsection{Cell Phenotypic Assays}

To evaluate the cell migration capacity, we performed a wound healing assay. Briefly, $2 \times 10^{6}$ cells of recipient cells were cultured, in a 6-multi well plate and, after $24 \mathrm{~h}$, a scratch was performed in the confluent cell monolayer and the HCT 116-EVs' conditions 1 and 2 were added with $1.5 \mathrm{~mL}$ of exo-free medium. The scratch distances and wound closure was evaluated using the beWound software (beWound-Cell Migration tool (Version 1.5)) [41]. The relative migration distances were calculated according to the following formula: \% of wound closure $=100 \times\left(\mathrm{d}_{0}-\mathrm{d}_{\mathrm{t}}\right) /$ mean of $\mathrm{d}_{0}$, where $\mathrm{d}_{0}$ is the width of cell wounds at time point $0 \mathrm{~h}$, and $\mathrm{d}_{\mathrm{t}}$ is the width of cell wounds at different time points. Additionally, in the moment of scratch closure, a proliferation assay was made. To analyze cell proliferation, $2 \times 10^{5}$ recipient cells were plated per well in a 96 multi-well and, after $24 \mathrm{~h}$, the HCT 116-EVs were administrated in the two concentrations $\left(5.3 \times 10^{8} \mathrm{EVs} / \mathrm{mL}\right.$ and $15.9 \times 10^{8} \mathrm{EVs} / \mathrm{mL}$ ), as described above. After $24 \mathrm{~h}$ of incubation, the WST-1 reagent (Abcam ${ }^{\circledR}$, Cambridge, United King) was added and incubated for $1 \mathrm{~h}$ and the absorbance was read at $450 \mathrm{~nm}$.

\subsubsection{EVs' Impact on Transcriptional Profile of Recipient Cells}

To analyze the effect of EVs' mRNA cargo in the recipient cells, $2 \times 10^{6}$ cells (of each of the recipient cells analyzed) were seeded in a 6 multi-well plate and, after $24 \mathrm{~h}$, the medium was replaced by exo-free medium and the HCT 116-EVs' conditions 1 and 2 were administrated. Following $24 \mathrm{~h}$, the cells were trypsinized and the total of $7 \times 10^{6}$ cells of each cell line were recovered for mRNA extraction. The protocol used for mRNA extraction, quantification, and analysis was as previously described in Section 2.4.

\subsubsection{LAT1 and ASCT2 Protein Levels' Analysis}

To quantify the protein levels of LAT1 and ASCT2, we performed a Western blot assay. For protein extraction, $2 \times 10^{6}$ cells were cultured in the respective culture medium. When cells reached a confluence of 80-90\%, they were trypsinized and centrifuged for $10 \mathrm{~min}$ at $2500 \times g$, at $4{ }^{\circ} \mathrm{C}$. The pellet was then lysed with $150 \mu \mathrm{L}$ of RIPA buffer (Radioimmunoprecipitation Assay Buffer) (Santa Cruz Biotechnology ${ }^{\circledR}$, Dallas, TX, USA) and supplemented with $1.5 \mu \mathrm{L}$ of phosphatase inhibitor cocktail (Thermo Fisher Scientific ${ }^{\circledR}$ ). Subsequently, the cell lysates were centrifugated for $15 \mathrm{~min}$ at $14,000 \times g$, at $4{ }^{\circ} \mathrm{C}$, and the supernatant was recovered for protein quantification using a DC Protein Assay (BioRad Laboratories ${ }^{\circledR}$, Hercules, CA, USA), measuring the solution's absorbance at $750 \mathrm{~nm}$. The electrophoretic separation of proteins $(20 \mu \mathrm{g})$ was performed in Mini-Protean TGX Gels $(4-20 \%)$ (BioRad Laboratories ${ }^{\circledR}$ ). The separated proteins were electrotransferred to polyvinylidene difluoride (PVDF) membranes (BioRad Laboratories ${ }^{\circledR}$ ) and blocked using 5\% BSA (Albumin Bovine Fraction V) (Enzytech ${ }^{\circledR}$, Lisbon, Portugal) in Tris-buffered saline with Tween20 (TBS-T). Following on, the membranes were incubated with primary antibodies (LAT1 (5347S) (1:250) (Cell Signaling Technology ${ }^{\circledR}$, Danvers, MA, USA), ASCT2 (8057S) (1:800) (Cell Signaling Technology $\left.{ }^{\circledR}\right)$, GAPDH (1:800) (sc-365062) (Santa Cruz Biotechnology $\left.{ }^{\circledR}\right)$ ), overnight at $4{ }^{\circ} \mathrm{C}$. Subsequently, the membranes were incubated with conjugated secondary antibodies (anti-mouse (sc-2005) $(1: 10,000)$ (Santa Cruz Biotechnology ${ }^{\circledR}$ ) and anti-rabbit $(7074 S)$ (1:3000) (Cell Signaling Technology $\left.{ }^{\circledR}\right)$ ) for $1 \mathrm{~h}$ at room temperature. The chemiluminescence was evaluated using ECL ${ }^{\mathrm{TM}}$ Prime Western Blotting System (Cytiva ${ }^{\mathrm{TM}}$, Amersham, UK), according to manufacturer's instructions. The experiment was replicated 2 times.

\subsection{Statistical Analysis}

Statistical analysis was made using IBM ${ }^{\circledR}$ SPSS ${ }^{\circledR}$ Statisticals for Windows v23. To evaluate the statistic differences in the normalized expression levels of the mRNAs, the $2^{-\Delta \Delta \mathrm{Cq}}$ method, along with the Student's $t$-test were used [42]. Data are expressed as the mean \pm standard error for each group. One-way analysis of variance was used to analyze the difference between groups and the least significance difference test was used for comparisons between two groups. $p<0.01$ and $p<0.05$ were considered to indicate a 
statistically significant difference. Additionally, GraphPad Prism 8 was used for graphical presentation of the data.

\section{Results}

\subsection{Cell Lines Transcriptional Profile Characterization}

As previously mentioned, the transcriptional levels of LAT1 and ASCT2 mRNA were quantified by real-time qPCR in the HCT 116, SK-HEP-1, HEPG-2, HCA-7 and HKC-8 cell lines. Moreover, we also analyzed the levels of EGFR, VEGFA, CXCR4 and HIF1-A mRNAs, considering their oncogenic potential role. We found higher expression levels of LAT1 mRNA in the HCT 116 cell line compared to SK-HEP-1 $(p<0.001)$ and HKC-8 $(p=0.001)$ cell lines (Figure 1A). The HCT 116 cell line also presented higher levels of ASCT2 mRNA compared to HCA-7 $(p<0.001)$, SK-HEP-1 $(p<0.001)$, HEPG-2 $(p=0.035)$ and HKC-8 $(p<0.001)$ (Figure 1A).

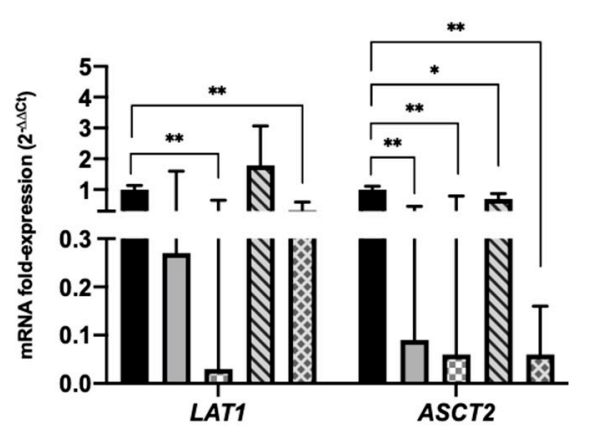

B

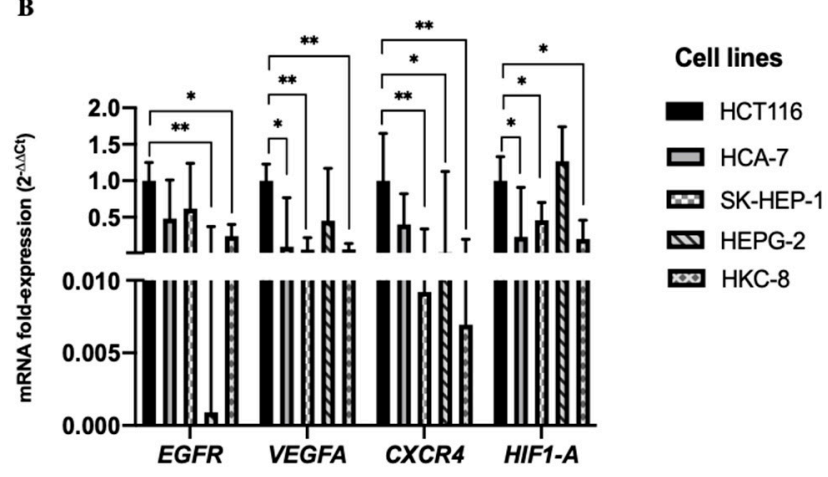

Figure 1. The bars represent the fold change of the mRNAs' expression, normalized to B2M. Expression levels shown are means of three technical replicates for each sample. (A) The graphs show the increase of LAT1 and ASCT2 mRNA and (B) EGFR, VEGFA, CXCR4 and HIF1-A mRNAs expression levels in HCT 116 cells, compared to the others cell lines in the analyzed panel. (Mean \pm Std. Error, ** $p<0.001, * p<0.05)$.

Regarding the EGFR mRNA levels, we also found an increase in the expression levels in the HCT 116 cell line compared to the HEPG-2 $(p<0.001)$ and HKC-8 $(p=0.001)$ cell lines. We also observed higher mRNA levels of VEGFA, CXCR4 and HIF1-A mRNAs in the HCT 116 cell line compared to the SK-HEP-1 and HKC-8 cell lines. Concerning the VEGF $(p=0.001)$ and HIF1-A $(p=0.020)$ mRNAs, higher levels were also found in the HCT 116 compared to the other CRC cell line, HCA-7. The HEPG-2 cell line presented lower levels of CXCR4 ( $p=0.002)$ mRNA compared to the HCT 116 (Figure 1B).

\subsection{HCT 116-EVs' Characterization}

The EVs were characterized according to size, shape, and quantity. The NTA analysis indicated that the vast majority of isolated EVs presented a mean size of $128 \mathrm{~nm}$, which is consistent with the size of small EVs (Figure 2A). These results are consistent with the flow cytometry analysis, where were found the presence of EVs smaller than $160 \mathrm{~nm}$ (Figure 2B-D). The Transmission Electron Microscopy (TEM) image (Figure 2E) shows the variability of morphology presented in HCT 116-EVs. Additionally, we validated the presence of LAT1, ASCT2, EGFR, HIF1-A, CXCR4 and VEGFA mRNAs in HCT 116-EVs (Figure 2F). 
$\mathbf{A}$

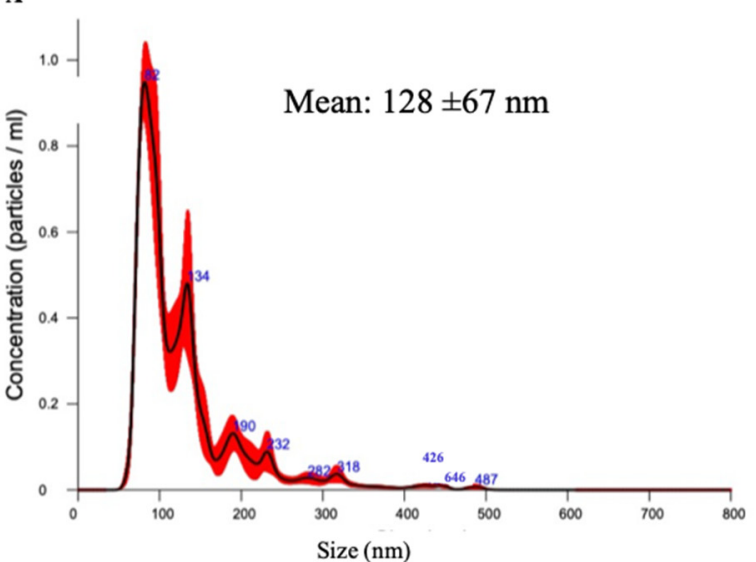

B
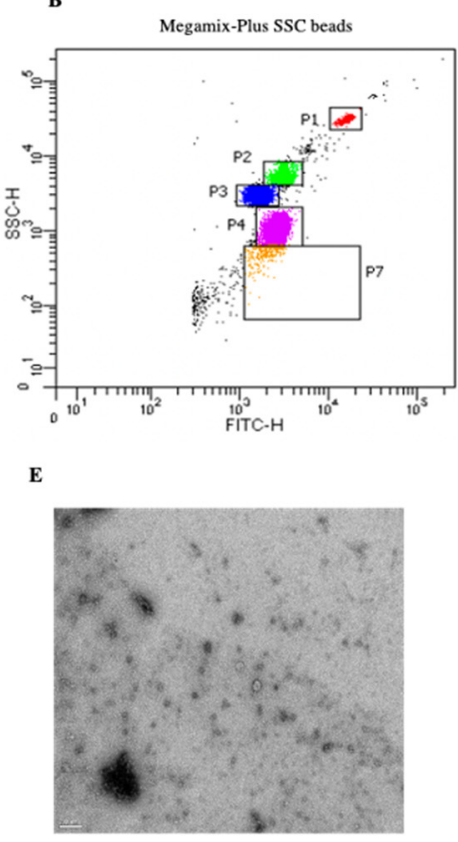

Fluorescent EV's stained with CFSE
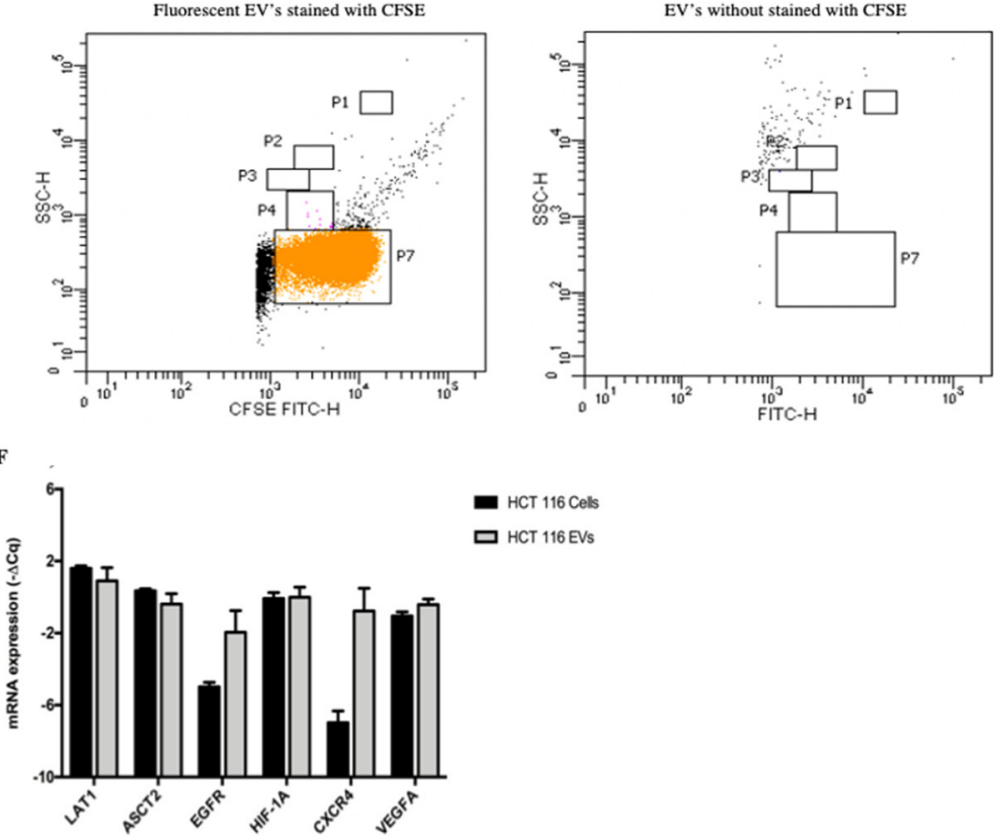

HCT 116 Cels

口 HCT 116 EVs

Figure 2. (A) NTA analysis of HCT 116-EVs showing the size distribution of EVs. (B) Megamix-Plus SSC beads used to define the cytometer settings for EVs' acquisition, with the following diameters: $0.5 \mu \mathrm{m}$ (gate P1), $0.24 \mu \mathrm{m}$ (gate P2), $0.20 \mu \mathrm{m}$ (gate P3) and $0.16 \mu \mathrm{m}$ (gate P4); (C) Fluorescent EVs (approximately $2.6 \times 10^{5} / 200 \mu \mathrm{L}$ ) as observed by flow cytometry from a sample of EVs isolate derived from HCT 116 cell line stained with CFSE (gate P7); (D) Negative control of EVs isolate derived from HCT 116 cell line without previous staining (gate P7). (E) Transmission electron microscopy (TEM) of EVs derived from HCT 116 cell line (scale $200 \mathrm{~nm}$ ). The TEM image was acquired in the Histology and Electron Microscopy platform from I3S Porto using a Transmission Electron Microscope Jeol JEM 1400. (F) The bars represent the $-\triangle \mathrm{Cq}$ of the mRNAs' expression, normalized to $B 2 M$. The graph shows the presence of intracellular and EVs related mRNAs levels (LAT1, ASCT2, EGFR, HIF1-A, $C X C R 4$ and VEGFA) derived from HCT 116 cell line. (Mean \pm Std. Error).

\subsection{HCT 116-EVs' Uptake Effect on HCA-7, SK-HEP-1, HEPG-2 and HKC-8 Recipient Cells}

Firstly, we analyzed the internalization/uptake of HCT 116-EVs in HCA-7, HEPG-2, SK-HEP-1 and HKC-8 recipient cell lines. As we can observe in Figure 3, the CFSE labeled HCT 116-EVs were internalized by all recipient cell lines (right images of Figure 3), validating the concept of cellular communication through EVs' networks. 


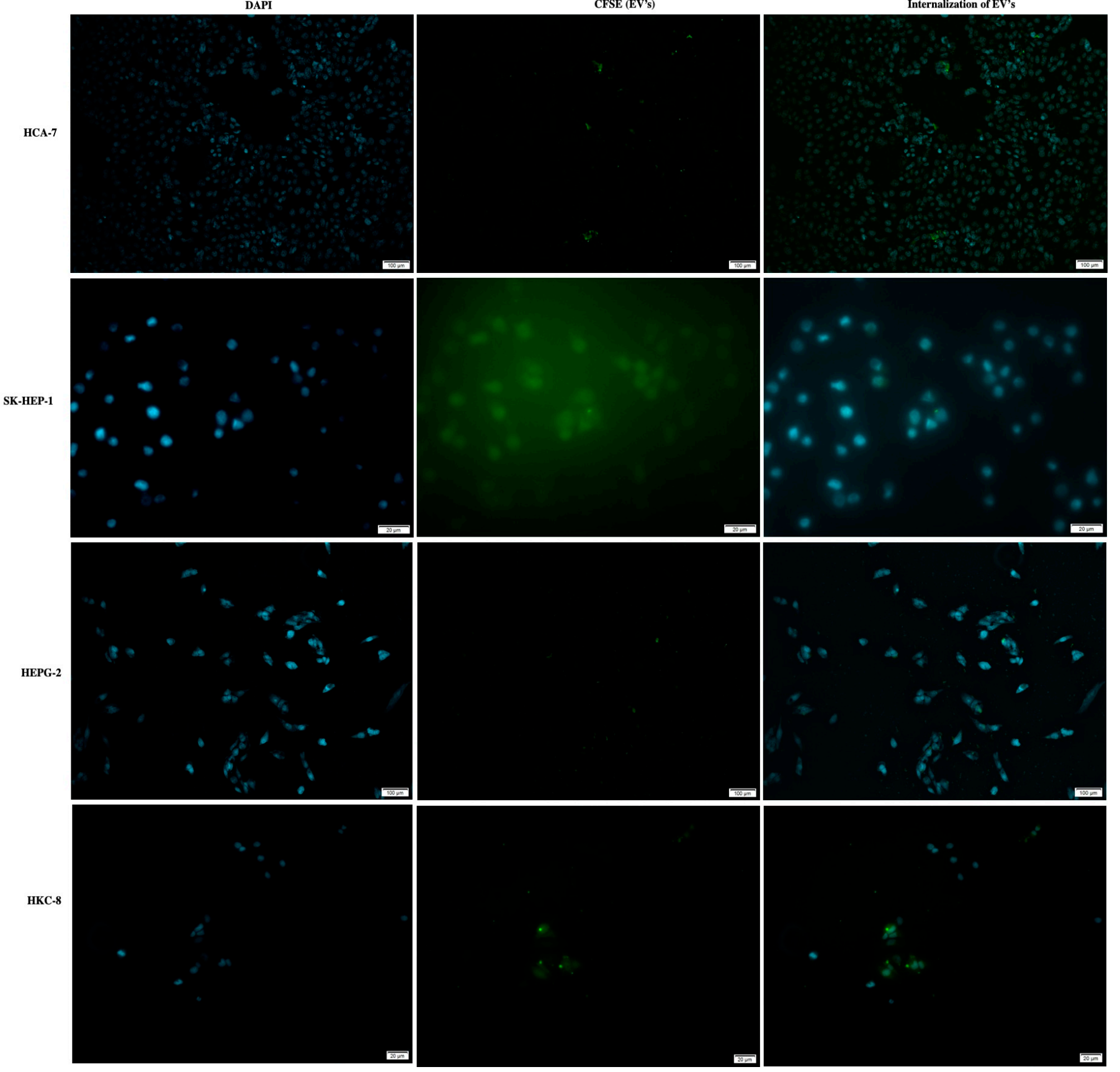

Figure 3. Representative immunofluorescence image shows the internalization of HCT 116-EVs labeled with CFSE (green dye) by HCA-7, SK-HEP-1, HEPG-2 and HKC-8 cells. The cell's nucleus is stained with DAPI (blue dye). (10X Olympus ${ }^{\circledR}$ IX51 microscope).

We then evaluated the HCT 116-EV's effect (condition 1: $5.3 \times 10^{8} \mathrm{EV}$ 's $/ \mathrm{mL}$ and condition 2: $15.9 \times 10^{8} \mathrm{EV}^{\prime} \mathrm{s} / \mathrm{mL}$ ) on cell proliferation and migration (Figure $4 \mathrm{~A}-\mathrm{D}$ ) and proliferation capacity (Figure 4G-J) of the recipient cells: HCA-7 (Figure 4A,G); SK-HEP-1 (Figure 4B,H); HEPG-2 (Figure 4C,I) and HKC-8 (Figure 4D,J). 

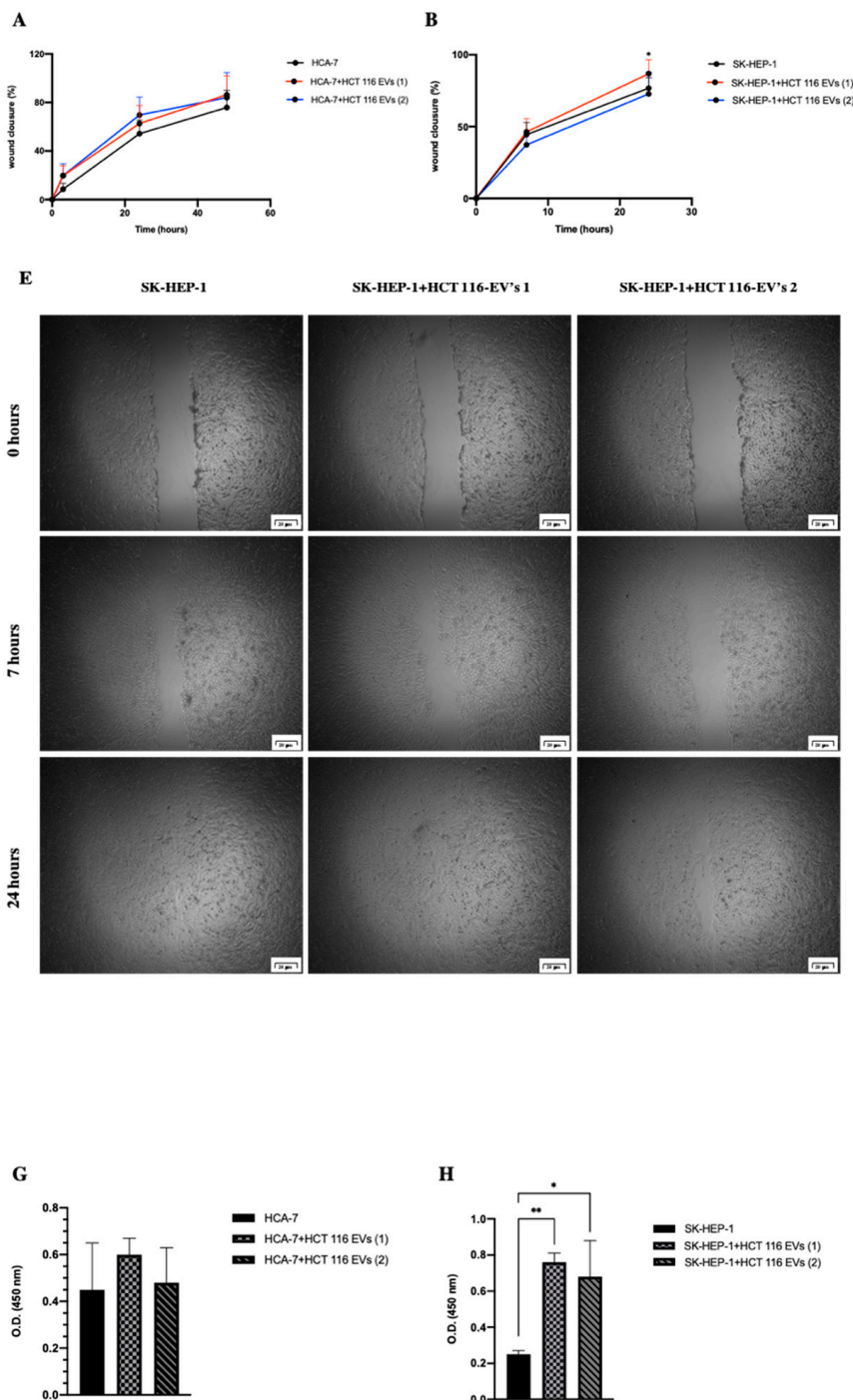

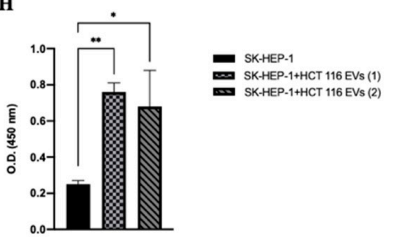

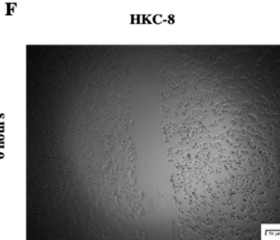
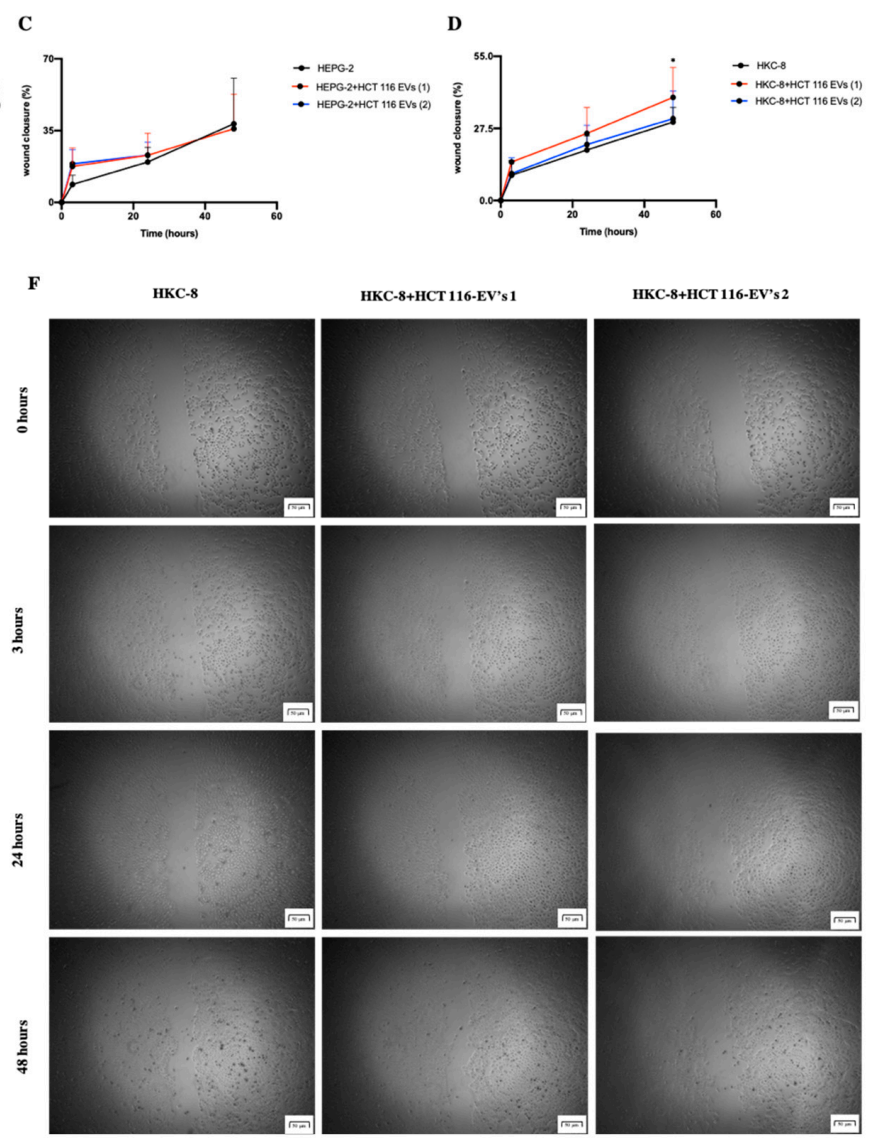

I

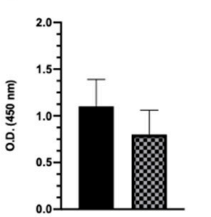

$\mathbf{J}$

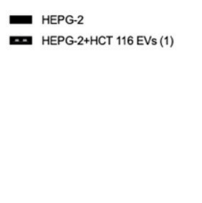

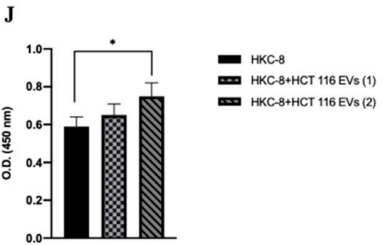

Figure 4. HCT 116-EVs' uptake in HCA-7 (A), SK-HEP-1 (B), HEPG-2 (C) and HKC-8 (D), respectively, affects cell migration capacity of recipient cells, with HCT 116-EVs condition 1 being able to induce an increase in gap closure in SK-HEP-1 and HKC-8 recipient cells. Representative images of wound healing assay in (E) SK-HEP-1 and (F) HKC-8 cells with internalization of HCT 116-EVs (conditions 1 and 2). Additionally, the HTC 116-EVs' uptake induces a higher proliferation rate in receptor cells SK-HEP-1 (H) and HKC-8 cells (J). However, this effect was not found in HCA-7 (G) or in HEPG-2 (I). The represented phenotypic assays were replicated three times for each sample. The statistical analysis was performed between the control group (recipient cells) and recipient cells after uptake of HCT 116-EVs (condition 1 and condition 2) in cells, at the same time point. (Mean \pm Std. Error, $\left.{ }^{* *} p<0.001,{ }^{*} p<0.05\right)$. (E) Scale bar $=20 \mu \mathrm{m}$; (F) Scale bar $=50 \mu \mathrm{m}$.

The figures of the wound healing assays of all recipient cells can be observed in the Supplementary Material (Figure S1). All the represented statistical analyses were performed between the control condition (recipient cells) and the uptake internalization (HCT 116-EVs 1 or HCT 116-EVs 2), at the same time point. According to the results, the uptake of HCT 116-EVs 1 by the SK-HEP-1 ( $p=0.002)$ and HKC-8 $(p=0.0017)$ cells was able to induce a migration advantage with a significantly higher percentage of wound closure when compared with the control condition (Figure 4A,C,D). Moreover, we also observed that the uptake of HCT 116-EVs condition 1 was able to induce a higher migration capacity in SK-HEP-1 in comparison to the internalization of HCT 116-EVs condition 2. Additionally, we also saw the effect of HCT 116-EVs condition 2 in HKC-8 cells, with an increase of their proliferation and migration capacity. Concerning HEPG-2 cells, we 
observed cell detachment in HCT 116-EVs condition 2, which did not allow the analysis of this experimental condition. Regarding the HCA-7 cells, after $48 \mathrm{~h}$ of the HCT 116-EVs' incubation, an increase of migration capacity was observed, when compared to the control condition.

The proliferation results are in agreement with the results observed for the migration capacity since we observed a higher proliferation rate in SK-HEP-1 $(p<0.001)$ after HCT 116-EVs condition 1's uptake (Figure 4B). Additionally, there was also a significant increase of proliferation capacity of SK-HEP-1 $(p=0.003)$ and HKC-8 $(p=0.002)$ after stimulus with HCT 116-EVs 2. Thus, these results demonstrated that HCT 116-EVs promote cell migration capacity and proliferation of specific recipient cells, namely of SK-HEP-1 and HKC-8.

Considering the impact of the EVs' cargo on recipient cells, we also analyzed the effect of HCT 116-EVs on the transcriptional profile of the different recipient cells (Figure 5). In SK-HEP-1 cell line, we observed an increase of LAT1 $(p=0.049)$ mRNA levels after HCT 116-EVs 1's uptake, and a decrease of VEGFA mRNA levels $(p<0.001)$ after HCT 116-EVs $2^{\prime}$ uptake (Figure 5B,F). Concerning the effect of the EVs' uptake in the HKC-8 cell line (Figure 5D,H), we observed a decrease of HIF1- $A(p=0.019)$ mRNA levels after HCT 116-EVs 2's uptake. Regarding the other cell lines, we did not find any statistically significant differences after HCT 116-EVs' uptake.

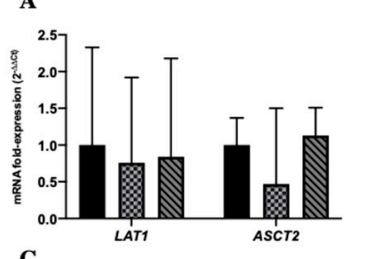

C

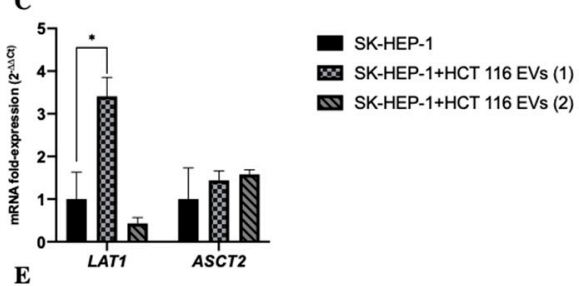

$\mathbf{E}$

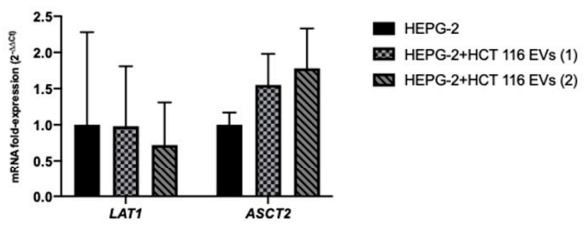

G

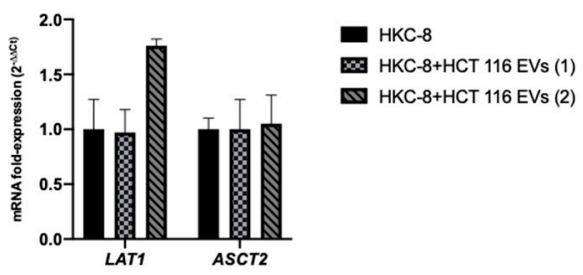

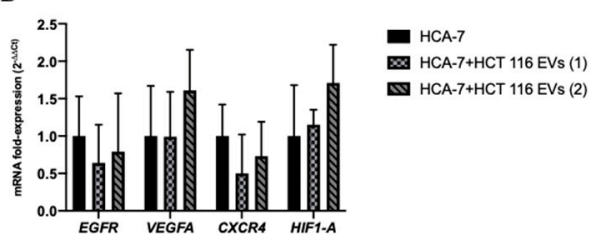

D

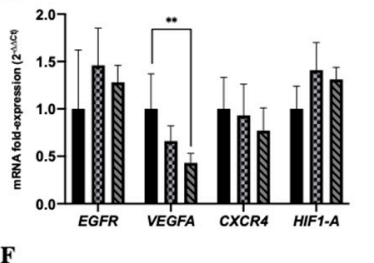

- SK-HEP-1

SK-HEP-1+HCT 116 EVs (1)

SK-HEP-1+HCT 116 EVs (2)

F

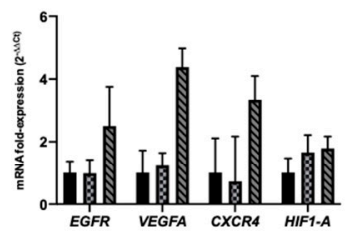

- HEPG-2

HEPG-2+HCT $116 \mathrm{EVS}(1)$

HEPG-2+HCT 116 EVs (2)

H

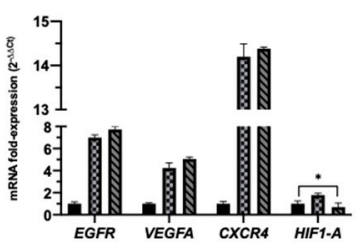

HKC-8

HKC-8+HCT 116 EVs (1) HKC-8+HCT 116 EVs (2)

Figure 5. The bars represent the fold change of the mRNAs expression, normalized to $B 2 M$. Variation of levels of LAT1, ASCT2, EGFR, VEGFA, CXCR4 and HIF1-A mRNAs in recipient cells after HCT 116-EVs' uptake. Three biological replicates of each cell line were used for this experiment. $(\mathrm{A}, \mathrm{C}, \mathrm{E}, \mathrm{G})$ The graphs demonstrate that the HCT 116-EVs condition 1's uptake leads to an increase of LAT1 mRNA expression level by SK-HEP-1 cells. (B,D,F,H) Additionally, the HCT 116-EVs condition 2's uptake decreases the expression level of VEGFA mRNA in SK-HEP-1 recipient cells. In HKC-8 recipient cells, the HCT 116-EVs condition 2 uptake induces a decrease of HIF-1A mRNA expression level. (Mean \pm Std. Error, ${ }^{* *} p<0.001,{ }^{*} p<0.05$ ). 
Regarding the protein levels, the bands were quantified, as exemplified in Figure 6E,F. According to the results, we found a decrease of LAT1 and ASCT2's protein level, when the HCA-7 cells were submitted to HCT 116-EVs' (conditions 1 and 2) stimulus (Figure 6A,E). Concerning the SK-HEP-1 cells, we observed an increase of LAT1's protein level after stimulus with HCT 116-EVs 1, compared to the control condition (Figure 6B,E). We also observed a change in the glycosylation status of ASCT2 after HCT 116-EVs' (conditions 1 and 2) stimulus in SK-HEP-1 cells, which led to ASCT2's protein expression in its nonglycosylated form, contrary to what happens in the control condition, where the ASCT2 protein is expressed in its glycosylated form. In HEPG-2 cells, we detected an increase of LAT1's protein levels, and a decrease of ASCT2's protein levels (Figure 6C,F). Additionally, we also found that in HCA-7 and HEPG-2, the glycosylation pattern of ASCT2 didn't change after the EVs' uptake, the ASCT2 protein being expressed mostly in its glycosylated form. In the HKC-8 cell line, we observed that the uptake of HCT 116-EVs (conditions 1 and 2) decreased LAT1's protein levels compared to the control condition. Regarding ASCT2, we found an increased trend of the protein levels after HCT 116-EVs 1 stimulus. Furthermore, we observed that in the HKC-8's basal condition and after HCT 116-EVs (1 and 2) stimulus, the ASCT2 expression is mostly expressed in its non-glycosylated form (Figure 6D,F).
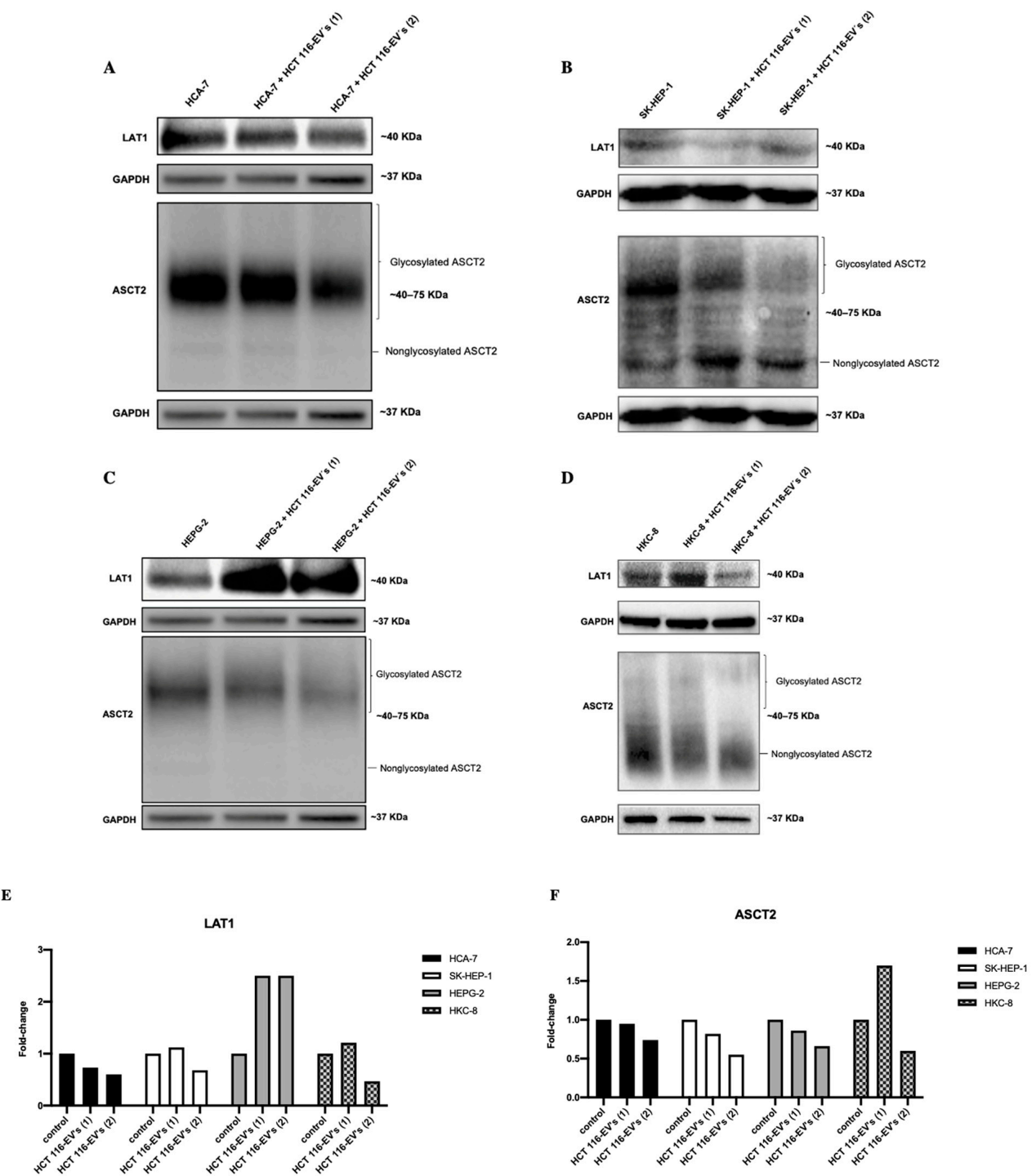

Figure 6. The experience was replicated two times for each sample. LAT1 and ASCT2 protein levels 
and HCT 116-EVs' uptake effects in (A) HCA-7, (B) SK-HEP-1, (C) HEPG-2 and in (D) HKC-8 cell lines. Fold-change of the pixels' volume adjusted intensity of (E) LAT1 and (F) ASCT2 protein levels, in recipient cells after HCT 116-EVs' uptake. The bands show that HCT 116-EVs condition 1 internalized by SK-HEP-1 induce an increase of LAT1 protein level. Similarly, in HEPG-2 recipient cells, after HCT 116-EVs' (condition 1 and 2) uptake, there is an increase of LAT1 protein levels. On the other hand, the internalization of HCT 116-EVs 1 by HKC- 8 cells leads to an increase of ASCT2 protein levels.

\section{Discussion}

One of the major concerns of CRC management is the fact that a high number of patients are diagnosed in advanced stages of disease, and that, in 50\% of patients diagnosed with local diseases, metastasis eventually develops. In 30-50\% of CRC patients, the liver is the predominant site of metastatic disease, in consequence of its drainage from the gastrointestinal tract $[4,6,43,44]$. In these cases, the only curative approach is surgery. However, a limited number of patients are considered eligible [44].

It is well established that the tumor microenvironment represents a complex network, in which tumor cells communicate with others cell types, including fibroblasts, endothelial cells and immune cells $[45,46]$. In recent years, the scientific community have focused on EVs' intercellular communication role, and their potential as vehicles and mediators of cell communication and cellular microenvironment modulation has already been demonstrated $[47,48]$. Studies demonstrated that cancer derived EVs participate in critical steps of pre-metastatic niche formation in the primary tumor by delivering cargo to recipient cells in target organs $[39,49]$. The pivotal role of EVs in regulating several immune-related pathways leading to activation, differentiation and expression of immune cells and modulation of the tumor microenvironment has already been demonstrated, as well as its significant role in CRC progression and metastasis [50]. Increasing evidence shows that mRNAs can be transferred to the surrounding microenvironment, via EVs' pathways, and influence the metabolism of recipient cells to favor cancer progression [49,51]. In fact, according to Chiba and colleagues, EVs derived from three CRC cells (HCT-15, SW480 and WiDr) showed the capacity to transfer mRNAs into 2D A549 cells (lung cancer cells) and HEPG-2 cell lines, validating that EVs-derived RNAs can be shuttled between cells, and can be involved in the regulation of gene expression in recipient cells [40]. Furthermore, Shao and co-workers described that CRC derived EVs present a pivotal role in promoting liver metastasis, by inducing a premetastatic niche through miR-21-TLR7-IL-6 axis [43]. These authors described that CRC-EVs can specifically target liver tissue and induce liver macrophages toward an IL-6 proinflammatory phenotype [43]. Additionally, the study mentions miR-21 as highly enriched in CRC-EVs, this miRNA being essential for creating a proinflammatory phenotype in the liver and creating liver metastasis in CRC [43]. Finally, the authors also demonstrate that silencing either miR-21 in CRC-EVs, or TLR-7 in macrophages, abolished the CRC-EVs' induction of proinflammatory macrophages [43]. Costa-Silva and co-workers described, for the first time, the sequential steps responsible for the formation of liver pre-metastatic niches (LPMN) supportive of PC metastasis, which involved binding of Macrophage Migration inhibitory factor (MIF)+ PC-derived EVs to liver Kupffer cells, followed by TGF- $\beta$ production by these cells. TGF- $\beta$, in turn, promoted fibronectin production by hepatic stellate cells, that supported the accumulation of bone marrow-derived macrophages, completing the LPMN formation [52]. More recently, Xuan and colleagues reported that EVs derived from breast cancer contribute to pre-metastatic niche formation and promote bone metastasis of tumor cells [53]. This process is mediated by EVs derived from breast cancer cells (SCP28 and MDA-MB-231 cells), which promote osteoclast differentiation and enhance bone metastasis [53]. Therefore, these studies suggest the role of EVs in metastasis establishment, through the transfer of biomolecular cargo, presenting a great potential to be used as predictive targets.

Nevertheless, there is still no evidence in the literature about the influence of LAT1 and ASCT2 mRNAs derived from CRC-EVs in CRC progression and metastasis, even though 
they play an important role in the growth and survival of CRC cancer cell lines, since they ensure the rapid exchange of AA and the maintenance of an AA pool in the cytosol [54]. In this study, we detected for the first time the presence of LAT1, ASCT2 and other oncogenic mRNAs on CRC-EVs, as well as their capacity to modify the transcriptional profile and phenotypic characteristics of recipient cell lines. Moreover, we showed the presence of EGFR, VEGFA, CXCR4 and HIF1-A mRNAs in CRC-EVs, which is in agreement with several evidences that support the involvement of these molecules in CRC development and metastases formation [26,55-64]. The overexpression of EGFR, HIF-1 $\alpha$ and VEGFA has been described in CRC, being associated with poor prognosis, aggressiveness, and a higher potential of metastases formation $[59,62,65]$. Moreover, CXCR4 is also correlated with poor histological differentiation, distant metastasis and lymph node metastasis, being its higher levels associated with poor prognosis in CRC patients [66].

Thus, we hypothesize that the incorporation of these molecules on EVs are essential to trigger the establishment of a microenvironment that supports the metastases' formation. In fact, we observed an increase of LAT1 and a decrease of VEGFA mRNAs in SK-HEP-1, and an increase of HIF1- $A$ mRNA levels in HKC-8 cells after stimulus with HCT 116EVs. These molecular changes may be associated with the release of pro-inflammatory cytokines such as IL-6, leading to an inflammatory process which is influenced by cellular metabolism and hypoxia [67]. In fact, Quan and colleagues, showed that LAT1 was required for angiogenic processes, since VEGFA's stimulus induced LAT1 overexpression that consequently triggered angiogenesis [68]. On the other hand, Shi and co-workers describe that, in non-small cell lung cancer, the expression of LAT1 is correlated with HIF1-A levels $[69,70]$. Therefore, according to our results, we can assume that an increase in $H I F-1 A$ and hypoxia leads to an increase of LAT1 expression [70]. Interestingly, the increase of LAT1 mRNA in the SK-HEP-1 cell line, after HCT 116-EVs' uptake, was able to support the high demand of amino acids by these cells. In fact, the increase of LAT1 mRNA in SK-HEP-1 translated into the increase of LAT1 protein expression, cell proliferation, as well as in the invasion capacity of these cells. Wang and co-workers had already reported higher protein levels of CXCR4 in the liver of the HT-29-derived exosome-treated Caco-2implanted mice [71].

Interestingly, we also observed that the internalization of different concentrations of HCT 116-EVs cause different effects in recipient cells. In fact, we observed that SKHEP-1 cells reach a saturation peak after HCT 116-EVs condition 1's stimulus for around $24 \mathrm{~h}$. Additionally, we also saw that there is a dose dependency of EVs administrated to SK-HEP-1 recipient cells, since the migration and proliferation capacity displayed a strong dose dependence with a minimal effective dose of $5.3 \times 10^{8} \mathrm{EVs} / \mathrm{mL}$ (HCT 116-EVs condition 1). Similarly, Franzen and colleagues also demonstrated that the EVs' uptake by recipient cells is time and dose dependent, a peak of EVs' internalization occurring before the $24 \mathrm{~h}$ of incubation [72]. These authors described that the recipient cells reached a saturation point of exosomes internalization after $14 \mathrm{~h}$, however, after $24 \mathrm{~h}$ of stimulus the authors demonstrated that exosomes continued to be taken up by cells [72]. Similarly, Jurgielewicz and co-workers also describe that HEK293T-EVs' uptake is time and dose dependent, the peak of uptake being around $12 \mathrm{~h}$ [73]. Moreover, the authors also report that after a dose of $6000 \mathrm{EVs} /$ cell are taken up by HEK293T recipient cells, these reach a dose saturation limit [73]. Jurgielewicz and co-workers also report that since EVs have shown to be internalized then released after $24 \mathrm{~h}$, longer incubations may generate inaccurate internalizations readouts [73]. In fact, after $48 \mathrm{~h}$ of incubation with HCT 116-EVs condition 2 , the results of migration and proliferation assays in HKC-8 cells seem to be inconsistent, which could be consequence of the long EVs' incubation period, and could be associated in an inaccurate internalization readout.

Considering the key role of LAT1 during CRC progression, and specially the capacity of tumor cells to encapsulate mRNA molecules inside EVs to modulate the surrounding microenvironment, the development of pharmacological strategies based on the inhibition of LAT1 could be promising for CRC patients' management. In fact, Okano and co-workers 
have already reported that JPH203, a LAT1 inhibitor, demonstrated potential to be used for CRC patients' treatment [23]. In a phase I study, JPH203 treatment was well tolerated by patients and led to disease control in two of the six CRC patients and in three of the five patients with biliary tract cancer [23].

The upregulation of LAT1 mRNA could also be associated with changes in the ASCT2 glycosylation pattern. In fact, a study performed by Polet and colleagues reports that glucose availability regulates the glycosylation of ASCT2 [74]. The authors describe that inhibition of glucose metabolism prevents ASCT2 glycosylation and promotes LAT1 upregulation as a countertrading mechanism of glycosylation's inhibition [74]. We observed a change in the ASCT2 glycosylation pattern after HCT116-EVs stimulus. The changes previously described in SK-HEP-1 were also followed by changes in ASCT2 protein's conformation, that changed to a non-glycosylated form. This may be due to the fact that HCT 116-EVs stimulate metabolic deregulation of SK-HEP-1 cells, which could lead to an increase of glucose consumption by these cells, and consequently, lead to a change of the glycosylation status of the ASCT2 protein.

In conclusion, the present study supports the role of CRC-EVs as key mediators of tumoral progression, supporting a proangiogenic and proliferative microenvironment establishment.

\section{Conclusions}

Our results uncovered an additional role of EVs in aggressive phenotypes of CRC, through the transference of LAT1 mRNA, with a phenotypic impact on cell proliferation and invasion capacity. Moreover, future studies should consider the replication of this in vitro study in a three-dimensional (3D) cell culture model to validate the cellular response to HCT 116-EVs' stimulus. These models provide more physiologically information and predictive data for in vivo tests since they mimic the biological conditions. In 3D cell culture models, cancer cells can maintain the shape, polarity and the heterogeneity observed in vivo. On the other hand, after the cell culture validation it will be crucial to check the influence of the HCT 116-EVs in animal models, to elucidate the role of this structure in the metastasis formation and clarify the metastatic routes of CRC. One possible approach to validate the hypothesis raised in this study may be to study if the inoculation of HCT 116-EVs only presents tropism for liver and kidney cells, or if they are able to affect the proliferation and migration capacity of cells from other organs. Additionally, it would also be interesting to validate our findings in CRC patients' plasma EVs to evaluate the biomarker potential of CRC EVs-derived mRNA, especially LAT1, in patients' prognoses and follow-ups. The validation of the biomarker potential of CRC EVs-derived mRNAs would be useful for liquid biopsies' implementation and the development of new therapeutic approaches for CRC.

Supplementary Materials: The following are available online at https:/ /www.mdpi.com/article/10 .3390/biology11010145/s1, Figure S1: Representative images of wound healing assay in (A) HCA-7, (B) SK-HEP-1, (C) HEPG-2 and (D) HKC-8 recipient cells, with respective uptakes of HCT 116-EVs (1 and 2), in the different time points. Figure S2: Representative original images of Western Blot assay in (A) HCA-7, HEPG-2, (B) SK-HEP-1 and (C) HKC-8 recipient cells, with respective uptakes of HCT 116-EVs (1 and 2).

Author Contributions: Conceptualization, A.L.T., F.D. and R.M.; methodology, C.A., F.D., V.M., M.M. and A.L.T.; validation, A.L.T., F.D. and R.M.; formal analysis, A.L.T., F.D., G.M., C.P., B.C.-S. and R.M.; investigation, C.A., A.L.T., F.D., V.M., M.E.S., I.G., S.B.; resources, A.L.T., G.M., C.P., B.C.-S. and R.M.; data curation, A.L.T., B.C.-S. and R.M.; writing-original draft preparation, C.A., V.M.; writing-review and editing, A.L.T., F.D., G.M., C.P., B.C.-S. and R.M.; supervision, F.D., A.L.T. and R.M.; project administration, A.L.T. and R.M.; funding acquisition, A.L.T. and R.M. All authors have read and agreed to the published version of the manuscript.

Funding: This research was supported by the Norte Portugal Region Operational Programme (NORTE 2020), under the PORTUGAL 2020 Partnership Agreement-Project SIRNAC—Novel siRNA 
therapies against metastatic colorectal cancer [NORTE-01-0247-FEDER-033399], and by the IPO-Porto Research Center [CI-IPO-21-2015].

Institutional Review Board Statement: Not applicable.

Informed Consent Statement: Not applicable.

Data Availability Statement: Not applicable.

Acknowledgments: The authors would like to thank the Research Department of the Portuguese League against Cancer Regional Nucleus of the North (LPCC-NRN). C.A. is a recipient of a research grant from LPCC-NRN.

Conflicts of Interest: The authors declare no conflict of interest. The funders had no role in the design of the study; in the collection, analyses, or interpretation of data; in the writing of the manuscript, or in the decision to publish the results.

\section{References}

1. Mármol, I.; Sánchez-De-Diego, C.; Pradilla Dieste, A.; Cerrada, E.; Rodriguez Yoldi, M. Colorectal Carcinoma: A General Overview and Future Perspectives in Colorectal Cancer. Int. J. Mol. Sci. 2017, 18, 197. [CrossRef] [PubMed]

2. Sung, H.; Ferlay, J.; Siegel, R.L.; Laversanne, M.; Soerjomataram, I.; Jemal, A.; Bray, F. Global Cancer Statistics 2020: GLOBOCAN Estimates of Incidence and Mortality Worldwide for 36 Cancers in 185 Countries. CA Cancer J. Clin. 2021, 71, 209-249. [CrossRef] [PubMed]

3. Yin, W.; Xu, J.; Li, C.; Dai, X.; Wu, T.; Wen, J. Circular RNA circ_0007142 Facilitates Colorectal Cancer Progression by Modulating CDC25A Expression via miR-122-5p. OncoTargets Ther. 2020, 13, 3689-3701. [CrossRef] [PubMed]

4. Al Bandar, M.H.; Kim, N.K. Current status and future perspectives on treatment of liver metastasis in colorectal cancer (Review). Oncol. Rep. 2017, 37, 2553-2564. [CrossRef] [PubMed]

5. Hur, K.; Toiyama, Y.; Okugawa, Y.; Ide, S.; Imaoka, H.; Boland, C.R.; Goel, A. Circulating microRNA-203 predicts prognosis and metastasis in human colorectal cancer. Gut 2017, 66, 654-665. [CrossRef]

6. Zarour, L.R.; Anand, S.; Billingsley, K.G.; Bisson, W.H.; Cercek, A.; Clarke, M.F.; Coussens, L.M.; Gast, C.E.; Geltzeiler, C.B.; Hansen, L.; et al. Colorectal Cancer Liver Metastasis: Evolving Paradigms and Future Directions. Cell. Mol. Gastroenterol. Hepatol. 2017, 3, 163-173. [CrossRef]

7. Fodde, R. The APC gene in colorectal cancer. Eur. J. Cancer 2002, 38, 867-871. [CrossRef]

8. Ward, P.; Thompson, C.B. Metabolic Reprogramming: A Cancer Hallmark Even Warburg Did Not Anticipate. Cancer Cell 2012, 21, 297-308. [CrossRef]

9. Pranzini, E.; Pardella, E.; Paoli, P.; Fendt, S.-M.; Taddei, M.L. Metabolic Reprogramming in Anticancer Drug Resistance: A Focus on Amino Acids. Trends Cancer 2021, 7, 682-699. [CrossRef]

10. Xie, J.; Zhu, X.Y.; Liu, L.M.; Meng, Z.Q. Solute carrier transporters: Potential targets for digestive system neoplasms. Cancer Manag. Res. 2018, 10, 153-166. [CrossRef]

11. Wu, Z.; Xu, J.; Liang, C.; Meng, Q.; Hua, J.; Wang, W.; Zhang, B.; Liu, J.; Yu, X.; Shi, S. Emerging roles of the solute carrier family in pancreatic cancer. Clin. Transl. Med. 2021, 11, e356. [CrossRef]

12. Fuchs, B.C.; Bode, B.P. Amino acid transporters ASCT2 and LAT1 in cancer: Partners in crime? Semin. Cancer Biol. 2005, 15, 254-266. [CrossRef]

13. Nyquist, M.D.; Prasad, B.; Mostaghel, E.A. Harnessing Solute Carrier Transporters for Precision Oncology. Molecules 2017, 22, 539. [CrossRef]

14. Wang, Q.; Holst, J. L-type amino acid transport and cancer: Targeting the mTORC1 pathway to inhibit neoplasia. Am. J. Cancer Res. 2015, 5, 1281-1294.

15. Hayase, S.; Kumamoto, K.; Saito, K.; Kofunato, Y.; Sato, Y.; Okayama, H.; Miyamoto, K.; Ohki, S.; Takenoshita, S. L-type amino acid transporter 1 expression is upregulated and associated with cellular proliferation in colorectal cancer. Oncol. Lett. 2017, 14, 7410-7416. [CrossRef] [PubMed]

16. Napolitano, L.; Scalise, M.; Galluccio, M.; Pochini, L.; Albanese, L.M.; Indiveri, C. LAT1 is the transport competent unit of the LAT1/CD98 heterodimeric amino acid transporter. Int. J. Biochem. Cell Biol. 2015, 67, 25-33. [CrossRef] [PubMed]

17. Scalise, M.; Pochini, L.; Console, L.; Losso, M.A.; Indiveri, C. The Human SLC1A5 (ASCT2) Amino Acid Transporter: From Function to Structure and Role in Cell Biology. Front. Cell Dev. Biol. 2018, 6, 96. [CrossRef]

18. Song, W.; Li, D.; Tao, L.; Luo, Q.; Chen, L. Solute carrier transporters: The metabolic gatekeepers of immune cells. Acta Pharm. Sin. B 2020, 10, 61-78. [CrossRef] [PubMed]

19. Bai, X.; Moraes, T.F.; Reithmeier, R.A.F. Structural biology of solute carrier (SLC) membrane transport proteins. Mol. Membr. Biol. 2017, 34, 1-32. [CrossRef] [PubMed]

20. Jiang, H.; Zhang, N.; Tang, T.; Feng, F.; Sun, H.; Qu, W. Target the human Alanine/Serine/Cysteine Transporter 2(ASCT2): Achievement and Future for Novel Cancer Therapy. Pharmacol. Res. 2020, 158, 104844. [CrossRef] 
21. Scalise, M.; Pochini, L.; Galluccio, M.; Console, L.; Indiveri, C. Glutamine Transport and Mitochondrial Metabolism in Cancer Cell Growth. Front. Oncol. 2017, 7, 306. [CrossRef]

22. Ogawa, H.; Kaira, K.; Motegi, Y.; Yokobori, T.; Takada, T.; Katoh, R.; Osone, K.; Takahashi, R.; Katayama, C.; Oyama, T.; et al. Role of Amino Acid Transporter Expression as a Prognostic Marker in Patients With Surgically Resected Colorectal Cancer. Anticancer. Res. 2019, 39, 2535-2543. [CrossRef] [PubMed]

23. Okano, N.; Naruge, D.; Kawai, K.; Kobayashi, T.; Nagashima, F.; Endou, H.; Furuse, J. First-in-human phase I study of JPH203, an L-type amino acid transporter 1 inhibitor, in patients with advanced solid tumors. Investig. New Drugs 2020, 38, $1495-1506$. [CrossRef] [PubMed]

24. Scalise, M.; Galluccio, M.; Console, L.; Pochini, L.; Indiveri, C. The Human SLC7A5 (LAT1): The Intriguing Histidine/Large Neutral Amino Acid Transporter and Its Relevance to Human Health. Front. Chem. 2018, 6, 243. [CrossRef] [PubMed]

25. Verrey, F. System L: Heteromeric exchangers of large, neutral amino acids involved in directional transport. Pflug. Arch. 2003, 445, 529-533. [CrossRef]

26. Häfliger, P.; Charles, R.-P. The L-Type Amino Acid Transporter LAT1-An Emerging Target in Cancer. Int. J. Mol. Sci. 2019, 20, 2428. [CrossRef]

27. Toda, K.; Nishikawa, G.; Iwamoto, M.; Itatani, Y.; Takahashi, R.; Sakai, Y.; Kawada, K. Clinical Role of ASCT2 (SLC1A5) in KRAS-Mutated Colorectal Cancer. Int. J. Mol. Sci. 2017, 18, 1632. [CrossRef]

28. Toda, K.; Kawada, K.; Iwamoto, M.; Inamoto, S.; Sasazuki, T.; Shirasawa, S.; Hasegawa, S.; Sakai, Y. Metabolic Alterations Caused by KRAS Mutations in Colorectal Cancer Contribute to Cell Adaptation to Glutamine Depletion by Upregulation of Asparagine Synthetase. Neoplasia 2016, 18, 654-665. [CrossRef] [PubMed]

29. Miyo, M.; Konno, M.; Nishida, N.; Sueda, T.; Noguchi, K.; Matsui, H.; Colvin, H.; Kawamoto, K.; Koseki, J.; Haraguchi, N.; et al. Metabolic Adaptation to Nutritional Stress in Human Colorectal Cancer. Sci. Rep. 2016, 6, 38415. [CrossRef]

30. Wong, C.C.; Qian, Y.; Li, X.; Xu, J.; Kang, W.; Tong, J.H.; To, K.-F.; Jin, Y.; Li, W.; Chen, H.; et al. SLC25A22 Promotes Proliferation and Survival of Colorectal Cancer Cells With KRAS Mutations and Xenograft Tumor Progression in Mice via Intracellular Synthesis of Aspartate. Gastroenterology 2016, 151, 945-960.e6. [CrossRef]

31. Yun, J.; Rago, C.; Cheong, I.; Pagliarini, R.; Angenendt, P.; Rajagopalan, H.; Schmidt, K.; Willson, J.K.V.; Markowitz, S.; Zhou, S.; et al. Glucose Deprivation Contributes to the Development of KRAS Pathway Mutations in Tumor Cells. Science 2009, 325, 1555-1559. [CrossRef]

32. Namikawa, M.; Kakizaki, S.; Kaira, K.; Tojima, H.; Yamazaki, Y.; Horiguchi, N.; Satoru, K.; Oriuchi, N.; Tominaga, H.; Sunose, Y.; et al. Expression of amino acid transporters (LAT1, ASCT2 and xCT) as clinical significance in hepatocellular carcinoma. Hepatol. Res. 2014, 45, 1014-1022. [CrossRef]

33. Raposo, G.; Stoorvogel, W. Extracellular vesicles: Exosomes, microvesicles, and friends. J. Cell Biol. 2013, 200, 373-383. [CrossRef] [PubMed]

34. Wang, M.; Yu, F.; Ding, H.; Wang, Y.; Li, P.; Wang, K. Emerging Function and Clinical Values of Exosomal MicroRNAs in Cancer. Mol. Ther.-Nucleic Acids 2019, 16, 791-804. [CrossRef]

35. Zhou, J.; Li, X.-L.; Chen, Z.-R.; Chng, W.-J. Tumor-derived exosomes in colorectal cancer progression and their clinical applications. Oncotarget 2017, 8, 100781-100790. [CrossRef] [PubMed]

36. Kalluri, R. The biology and function of exosomes in cancer. J. Clin. Investig. 2016, 126, 1208-1215. [CrossRef]

37. Jella, K.K.; Nasti, T.H.; Li, Z.; Malla, S.R.; Buchwald, Z.S.; Khan, M.K. Exosomes, Their Biogenesis and Role in Inter-Cellular Communication, Tumor Microenvironment and Cancer Immunotherapy. Vaccines 2018, 6, 69. [CrossRef] [PubMed]

38. Akbar, N.; Azzimato, V.; Choudhury, R.P.; Aouadi, M. Extracellular vesicles in metabolic disease. Diabetologia 2019, 62, 2179-2187. [CrossRef]

39. Guo, Y.; Ji, X.; Liu, J.; Fan, D.; Zhou, Q.; Chen, C.; Wang, W.; Wang, G.; Wang, H.; Yuan, W.; et al. Effects of exosomes on pre-metastatic niche formation in tumors. Mol. Cancer 2019, 18, 39. [CrossRef]

40. Chiba, M.; Kimura, M.; Asari, S. Exosomes secreted from human colorectal cancer cell lines contain mRNAs, microRNAs and natural antisense RNAs, that can transfer into the human hepatoma HepG2 and lung cancer A549 cell lines. Oncol. Rep. 2012, 28, 1551-1558. [CrossRef]

41. Moreira, A.H.J.Q.S.; Vilaça, J.L. Biomedical Engineering Solutions Research Group LaHSRI, University of Minho. Available online: http://www.besurg.com/sites/default/files/beWoundApp.zip (accessed on 21 April 2020).

42. Livak, K.J.; Schmittgen, T.D. Analysis of relative gene expression data using real-time quantitative PCR and the 2(- $\Delta \Delta C T)$ Method. Methods 2001, 25, 402-408. [CrossRef]

43. Shao, Y.; Chen, T.; Zheng, X.; Yang, S.; Xu, K.; Chen, X.; Xu, F.; Wang, L.; Shen, Y.; Wang, T.; et al. Colorectal cancer-derived small extracellular vesicles establish an inflammatory premetastatic niche in liver metastasis. Carcinogenesis 2018, 39, 1368-1379. [CrossRef] [PubMed]

44. Birrer, D.L.; Tschuor, C.; Reiner, C.; Fritsch, R.; Pfammatter, T.; Schüler, H.G.; Pavic, M.; De Oliveira, M.; Petrowsky, H.; Dutkowski, P.; et al. Multimodal treatment strategies for colorectal liver metastases. Swiss Med. Wkly. 2021, 151, w20390. [CrossRef]

45. Maacha, S.; Bhat, A.A.; Jimenez, L.; Raza, A.; Haris, M.; Uddin, S.; Grivel, J.-C. Extracellular vesicles-mediated intercellular communication: Roles in the tumor microenvironment and anti-cancer drug resistance. Mol. Cancer 2019, 18, 55. [CrossRef]

46. Couto, N.; Caja, S.; Maia, J.; Moraes, M.C.S.; Costa-Silva, B. Exosomes as emerging players in cancer biology. Biochimie 2018, 155, 2-10. [CrossRef] [PubMed] 
47. Jurj, A.; Zanoaga, O.; Braicu, C.; Lazar, V.; Tomuleasa, C.; Irimie, A.; Berindan-Neagoe, I. A Comprehensive Picture of Extracellular Vesicles and Their Contents. Molecular Transfer to Cancer Cells. Cancers 2020, 12, 298. [CrossRef]

48. Console, L.; Scalise, M.; Indiveri, C. Exosomes in inflammation and role as biomarkers. Clin. Chim. Acta 2019, 488, 165-171. [CrossRef] [PubMed]

49. Yang, E.; Wang, X.; Gong, Z.; Yu, M.; Wu, H.; Zhang, D. Exosome-mediated metabolic reprogramming: The emerging role in tumor microenvironment remodeling and its influence on cancer progression. Signal Transduct. Target. Ther. 2020, 5, 242. [CrossRef]

50. Siveen, K.S.; Raza, A.; Ahmed, E.I.; Khan, A.Q.; Prabhu, K.S.; Kuttikrishnan, S.; Mateo, J.M.; Zayed, H.; Rasul, K.; Azizi, F.; et al. The Role of Extracellular Vesicles as Modulators of the Tumor Microenvironment, Metastasis and Drug Resistance in Colorectal Cancer. Cancers 2019, 11, 746. [CrossRef]

51. Lucchetti, D.; Tenore, C.R.; Colella, F.; Sgambato, A. Extracellular Vesicles and Cancer: A Focus on Metabolism, Cytokines, and Immunity. Cancers 2020, 12, 171. [CrossRef]

52. Costa-Silva, B.; Aiello, N.M.; Ocean, A.J.; Singh, S.; Zhang, H.; Thakur, B.K.; Becker, A.; Hoshino, A.; Mark, M.T.; Molina, H.; et al. Pancreatic cancer exosomes initiate pre-metastatic niche formation in the liver. Nat. Cell Biol. 2015, 17, 816-826. [CrossRef] [PubMed]

53. Yuan, X.; Qian, N.; Ling, S.; Li, Y.; Sun, W.; Li, J.; Du, R.; Zhong, G.; Liu, C.; Yu, G.; et al. Breast cancer exosomes contribute to pre-metastatic niche formation and promote bone metastasis of tumor cells. Theranostics 2021, 11, 1429-1445. [CrossRef] [PubMed]

54. Lopes, C.; Pereira, C.; Medeiros, R. ASCT2 and LAT1 Contribution to the Hallmarks of Cancer: From a Molecular Perspective to Clinical Translation. Cancers 2021, 13, 203. [CrossRef] [PubMed]

55. Khan, K.; Valeri, N.; Dearman, C.; Rao, S.; Watkins, D.; Starling, N.; Chau, I.; Cunningham, D. Targeting EGFR pathway in metastatic colorectal cancer- tumour heterogeniety and convergent evolution. Crit. Rev. Oncol. 2019, 143, 153-163. [CrossRef]

56. Wee, P.; Wang, Z. Epidermal Growth Factor Receptor Cell Proliferation Signaling Pathways. Cancers 2017, 9, 52. [CrossRef] [PubMed]

57. Mizukami, T.; Izawa, N.; Nakajima, T.E.; Sunakawa, Y. Targeting EGFR and RAS/RAF Signaling in the Treatment of Metastatic Colorectal Cancer: From Current Treatment Strategies to Future Perspectives. Drugs 2019, 79, 633-645. [CrossRef]

58. Lech, G.; Slotwinski, R.; Słodkowski, M.; Krasnodębski, I.W. Colorectal cancer tumour markers and biomarkers: Recent therapeutic advances. World J. Gastroenterol. 2016, 22, 1745-1755. [CrossRef]

59. Spano, J.-P.; Lagorce, C.; Atlan, D.; Milano, G.; Domont, J.; Benamouzig, R.; Attar, A.; Benichou, J.; Martin, A.; Morere, J.-F.; et al. Impact of EGFR expression on colorectal cancer patient prognosis and survival. Ann. Oncol. 2005, 16, 102-108. [CrossRef] [PubMed]

60. D'Ignazio, L.; Batie, M.; Rocha, S. Hypoxia and Inflammation in Cancer, Focus on HIF and NF-kB. Biomedicines 2017, 5, 21 [CrossRef]

61. Krock, B.L.; Skuli, N.; Simon, M.C. Hypoxia-Induced Angiogenesis: Good and Evil. Genes Cancer 2011, 2, 1117-1133. [CrossRef]

62. Mohamed, S.Y.; Mohammed, H.L.; Ibrahim, H.M.; Mohamed, E.M.; Salah, M. Role of VEGF, CD105, and CD31 in the Prognosis of Colorectal Cancer Cases. J. Gastrointest. Cancer 2019, 50, 23-34. [CrossRef] [PubMed]

63. George, M.L.; Tutton, M.G.; Janssen, F.; Arnaout, A.; Abulafi, A.M.; Eccles, S.A.; Swift, R.I. VEGF-A, VEGF-C, and VEGF-D in Colorectal Cancer Progression. Neoplasia 2001, 3, 420-427. [CrossRef] [PubMed]

64. Pozzobon, T.; Goldoni, G.; Viola, A.; Molon, B. CXCR4 signaling in health and disease. Immunol. Lett. 2016, 177, 6-15. [CrossRef] [PubMed]

65. Ioannou, M.; Paraskeva, E.; Baxevanidou, K.; Simos, G.; Papamichali, R.; Papacharalambous, C.; Samara, M.; Koukoulis, G. HIF- $1 \alpha$ in colorectal carcinoma: Review of the literature. J. Buon 2015, 20, 680-689.

66. Xu, C.; Zheng, L.; Li, D.; Chen, G.; Gu, J.; Chen, J.; Yao, Q. CXCR4 overexpression is correlated with poor prognosis in colorectal cancer. Life Sci. 2018, 208, 333-340. [CrossRef]

67. Shi, J.; Fan, J.; Su, Q.; Yang, Z. Cytokines and Abnormal Glucose and Lipid Metabolism. Front. Endocrinol. 2019, 10. [CrossRef]

68. Quan, L.; Ohgaki, R.; Hara, S.; Okuda, S.; Wei, L.; Okanishi, H.; Nagamori, S.; Endou, H.; Kanai, Y. Amino acid transporter LAT1 in tumor-associated vascular endothelium promotes angiogenesis by regulating cell proliferation and VEGF-A-dependent mTORC1 activation. J. Exp. Clin. Cancer Res. 2020, 39, 266. [CrossRef]

69. Shi, L.; Luo, W.; Huang, W.; Huang, S.; Huang, G. Downregulation of L-type amino acid transporter 1 expression inhibits the growth, migration and invasion of gastric cancer cells. Oncol. Lett. 2013, 6, 106-112. [CrossRef]

70. Kaira, K.; Oriuchi, N.; Takahashi, T.; Nakagawa, K.; Ohde, Y.; Okumura, T.; Murakami, H.; Shukuya, T.; Kenmotsu, H.; Naito, T.; et al. LAT1 expression is closely associated with hypoxic markers and mTOR in resected non-small cell lung cancer. Am. J. Transl. Res. 2011, 3, 468-478.

71. Wang, X.; Ding, X.; Nan, L.; Wang, Y.; Wang, J.; Yan, Z.; Zhang, W.; Sun, J.; Zhu, W.; Ni, B.; et al. Investigation of the roles of exosomes in colorectal cancer liver metastasis. Oncol. Rep. 2015, 33, 2445-2453. [CrossRef]

72. Franzen, C.; Simms, P.E.; Van Huis, A.F.; Foreman, K.E.; Kuo, P.C.; Gupta, G.N. Characterization of Uptake and Internalization of Exosomes by Bladder Cancer Cells. BioMed Res. Int. 2014, 2014, 619829. [CrossRef] [PubMed] 
73. Jurgielewicz, B.; Yao, Y.; Stice, S.L. Kinetics and Specificity of HEK293T Extracellular Vesicle Uptake using Imaging Flow Cytometry. Nanoscale Res. Lett. 2020, 15, 170. [CrossRef] [PubMed]

74. Polet, F.M.R.; Corbet, C.; Pinto, A.; Feron, O. Inhibition of glucose metabolism prevents glycosylation of the glutamine transporter ASCT2 and promotes compensatory LAT1 upregulation in leukemia cells. Oncotarget 2016, 7, 46371. [CrossRef] [PubMed] 